\title{
Intraplate mafic magmatism, degasification, and deposition of mercury: The giant Almadén mercury deposit (Spain) revisited
}

\author{
Pablo Higueras ${ }^{\mathrm{a}, *}$, Roberto Oyarzun ${ }^{\mathrm{b}}$, Javier Lillo ${ }^{\mathrm{c}}$, Diego Morata ${ }^{\mathrm{d}}$ \\ a Instituto de Geología Aplicada \& Departamento de Ingeniería Geológica y Minera. E.I.M.I. Almadén, Universidad de Castilla-La Mancha, Plaza Manuel Meca 1, \\ E-13400 Almadén (Ciudad Real), Spain \\ b Departamento de Cristalografia y Mineralogía, Facultad de Ciencias Geológicas, Universidad Complutense, 28040 Madrid, Spain \\ c Escuela Superior de Ciencias Experimentales y Tecnología, Universidad Rey Juan Carlos, Tulipán s/n, 28933 Móstoles, Madrid, Spain \\ d Departamento de Geologia \& Centro de Excelencia en Geotermia de los Andes (CEGA-FONDAP-CONICYT), Facultad de Ciencias Físicas y Matemáticas, Universidad de Chile, \\ Plaza. Ercilla 803, Santiago de Chile, Chile
}

\section{A R T I C L E I N F O}

\section{Article history:}

Received 25 February 2012

Received in revised form 3 December 2012

Accepted 14 December 2012

Available online 22 December 2012

\section{Keywords:}

Mercury

Intraplate alkaline magmatism

Mantle degasification

Almadén

Spain

\begin{abstract}
A B S T R A C T
The giant Almadén mercury deposit (Spain) is hosted by the Lower Silurian Criadero Quartzite; in turn this ore-bearing rock unit is cross-cut by the so-called Frailesca unit, a diatreme body of basaltic composition. The geochemical characteristics of the Silurian to Devonian Almadén District volcanic units indicate that these rocks originated from an enriched, evolving mantle source that ultimately yielded basanites-nephelinites to rhyolites, through olivine-basalts, pyroxene-basalts, trachybasalts, trachytes, very scarce rhyolites, and quartzdiabases. The Silurian intraplate alkaline volcanism developed in submarine conditions which triggered widespread hydrothermal activity resulting in $\mathrm{Hg}$ ore formation and pervasive alteration to carbonates. The $\delta^{18} \mathrm{O}, \delta^{13} \mathrm{C}$, and $\delta^{34} \mathrm{~S}$ isotopic signatures for carbonates and pyrite suggest different sources for carbon and sulfur, including magmatic and organic for the former and magmatic and sea water for the latter. The most important and efficient natural source of mercury on Earth is by far the volcanic activity, which liberates mercury via quiescent degassing and catastrophic (Plinian) events when eruptions can overwhelm the atmospheric budget of $\mathrm{Hg}$. Thus, we suggest that $\mathrm{CO}_{2}$ degasification and coeval distillation of mercury from the volcanic rocks fed the huge hydrothermal system that led to massive deposition of mercury at Almadén. Build up of $\mathrm{Hg}_{\text {gas }}^{0}$ in magmatic chambers during waning rifting in the Late Ordovician, followed by renewed volcanism in the Early Silurian, would have resulted in massive degasification of the accumulated mercury. Part of this mercury went into the Criadero Quartzite leading to formation of the huge Almadén deposit and others (e.g., El Entredicho) along the same stratigraphic level. Progressive depletion of the deep seated magmatic Hg stock would have resulted in a drastic reduction in ore deposit size after the Lower Silurian when smaller deposits formed (e.g., Las Cuevas).
\end{abstract}

(c) 2012 Elsevier B.V. All rights reserved.

\section{Introduction}

The Almadén district (Fig. 1) is the largest mercury geochemical cluster on Earth, having produced one third of the total world mercury production. Almadén has been to mercury what the Witwatersrand is to gold, with the difference that contrary to gold, mercury deposits are rare indeed. For example, only two mercury deposits of relative economic importance (Huancavelica, Perú; and Punitaqui, Chile) are present in the Andean chain, which is peculiar for one of the richest metallic provinces of the world. Furthermore, neither Huancavelica nor Punitaqui is 'one-metal-only' deposits such as Almadén. The district comprises several deposits; the main ones being Almadén, El Entredicho, Nueva and Vieja Concepción, and Las Cuevas (Fig. 1). Classic works on the geology of these mineral deposits include those of Saupé (1990), Higueras (1995), Hernández et al. (1999), Higueras et al. (1999a), and

\footnotetext{
* Corresponding author.

E-mail address: pablo.higueras@uclm.es (P. Higueras).
}

Palero and Lorenzo (2009), among others. The mining history of the Almadén district (Hernández et al., 1999) began some 2000 years ago, when Romans started to use cinnabar as a vermilion red pigment, but it was not until the Arabs invaded this realm that the locality acquired the etymological roots of its present name: Al-maaden (meaning "the mine"). However, the 'modern' history of Almadén and mercury begins in 1555, when the Spaniard Bartolomé de Medina (1497-1585) discovered the use of mercury in silver processing (Higueras et al., 2012). Thus, from the middle of the 16th Century Almadén had a major strategic importance for the colonization of America, becoming one of the largest early mining and metallurgical centers in Europe. Total production during the 16th and 17th Centuries is estimated at 17,250 t of mercury. Peak production was reached in 1941 with 82,000 flasks of mercury, a flask (or frasco as originally named in Spanish) being the standard weight unit for this metal, which is equivalent to $34.5 \mathrm{~kg} \mathrm{Hg}$. Mercury was in the past one of the leading export products of Spain, with price peaking at US\$571/flask in 1965 . Concerns about its environmental impact arose from the Minamata incident in Japan, which led to 

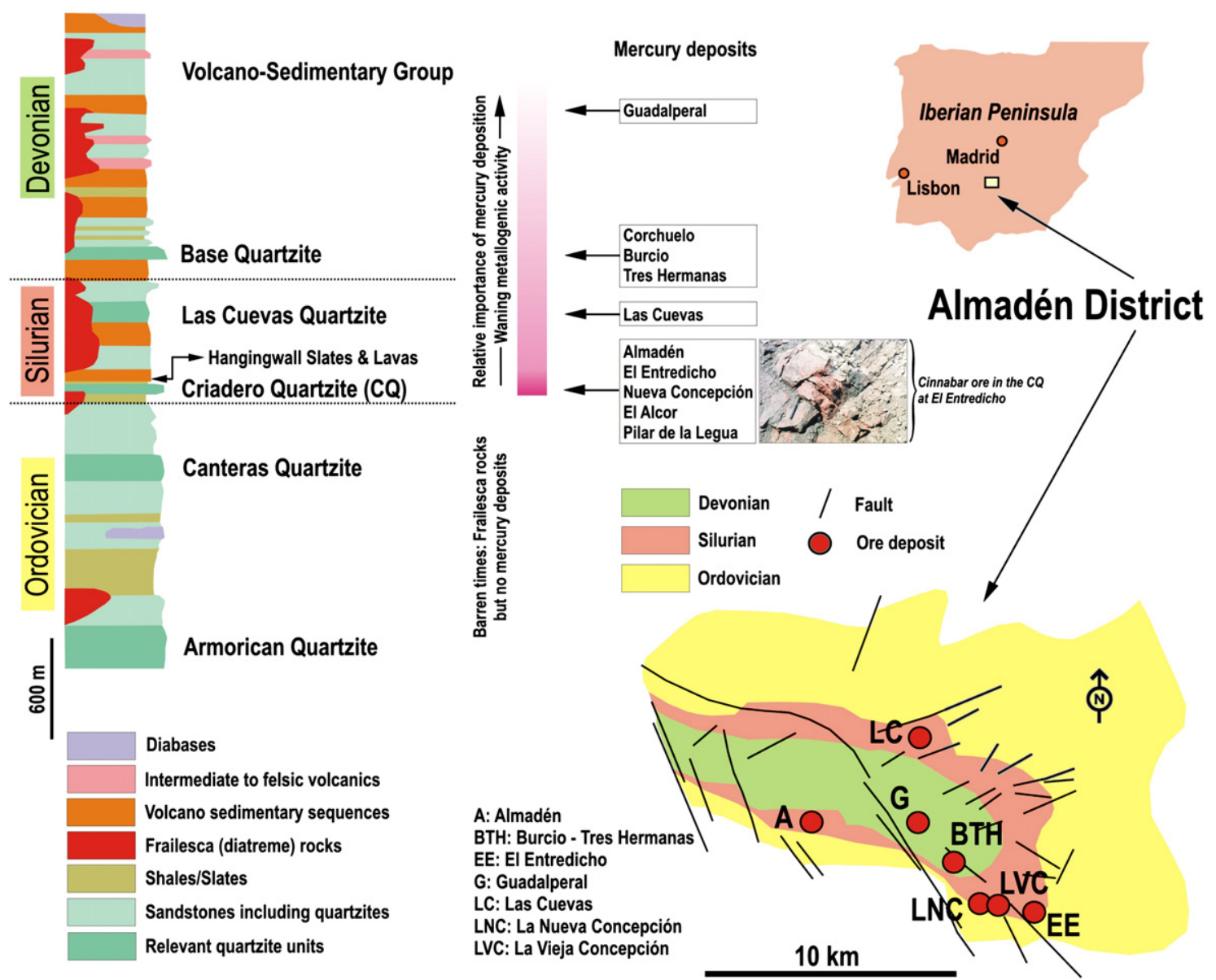

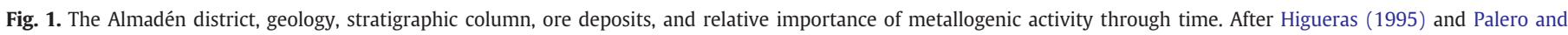
Lorenzo (2009); photograph: S. Lorenzo.

a sharp decrease in the world prices to US\$121/flask in 1976. A recovery in the late 1970s was due to the development of new small batteries for electronic devices. A final blow for Almadén came in the 2000's when the European Union (EU) banned all the use and sale of mercury, and made illegal the export of raw mercury and mercury compounds. Thus, at present all mercury products are to be regarded as 'toxic residues' and dealt with following EU directives. As a result all mining and metallurgical activities ceased in 2003, and the mine and installations have become a theme park for visitors.

Mining has ceased, but many of the uncertainties that surround the genesis of the giant mercury ore deposit of Almadén and others in the district still remain. We here argue that these unique mercury deposits required unusual geologic conditions, involving: 1) the existence of high porosity detrital rocks (the Criadero Quartzite and sister units); 2) coeval explosive volcanism under submarine conditions; and last but not least 3) a persistent enriched mantle source that ultimately led to the formation of the Almadén magmatic rocks. As we argue in this work, Almadén could be one of the few cases in which mafic intraplate volcanism has yielded economic mineralization of any type. We are not here presenting 'new' data on Almadén, but reviewing the geologic, petrologic and geochemical evidence to generate a conceptual model for the full district. This model involves aspects that were either neglected or its full importance inadequately recognized in the past: 1 ) the role of the intraplate mafic magmatism as a potential deep source of mercury; 2) the unparalleled efficiency of volcanism for degasification and even formation of $\mathrm{Hg}$ deposits; and last but not least 3 ) the post Lower Silurian persistent hydrothermal activity (up to Devonian time) that led to the formation of minor, however relevant deposits of mercury.

\section{Geology and ore deposits}

The Almadén district is located within the so-called Central Iberian Zone of the Iberian Variscan Massif (e.g., Dallmeyer and Martínez García, 1990). This realm is characterized by gentle anticlines and synclines, slaty cleavage in the metapelites, and a metamorphism of variable intensity. In the Almadén district the metamorphism reaches low-grade conditions, and has been dated at $335 \pm 15 \mathrm{Ma}(\mathrm{Rb} / \mathrm{Sr})$ in Ordovician shales (Nägler et al., 1992). The Paleozoic successions in this tectonic domain range in age from Lower Ordovician to Upper Devonian, and comprise five main quartzite units of Arenigian (Armorican Quartzite), Caradocian (Canteras Quartzite), Early Silurian (Criadero Quartzite), Upper Silurian (Las Cuevas Quartzite), and Siegenian (Base Quartzite) ages (Fig. 1). Slates and volcanic rocks complete a sequence of over $4000 \mathrm{~m}$ thick. Key for the understanding of the mercury deposits is the anomalous character of the Almadén syncline, which is the only tectonic unit in the Central Iberian Zone hosting significant intercalations of magmatic rocks.

As shown in Fig. 1, the Almadén mercury deposit is hosted by the Early Silurian Criadero Quartzite, which can be divided into four members at the Almadén mine (Palero and Lorenzo, 2009): 1) the Lower Quartzite, hosting the 3-8 $\mathrm{m}$ thick San Pedro mineralized bed; 2) a barren 10-15 m detrital sequence. 3) the Upper Quartzite, hosting the 2.5-5 m thick San Francisco and San Nicolás mineralized beds; and 4) a thin horizon of barren slates. The sequence is overlain by volcanic and sedimentary rocks and cross-cut by the Frailesca diatreme (Saupé, 1990) whereas the cinnabar mineralization occurs as impregnations within the high porosity quartzite rocks (Palero and Lorenzo, 2009). The metallic mineral paragenesis is extremely 
simple with cinnabar as the main mineral and minor pyrite. More than 250,000 t of mercury were extracted from the Almadén mine from block of mineralized beds of about $450 \times 600 \times 50 \mathrm{~m}$ (Saupé, 1990). Despite its size and structural complexity, the $\mathrm{Hg}$ isotope data for different mineralized beds at Almadén are very similar (Lauretta et al., 2001), which suggests a highly homogeneous mineralizing process during the formation of the deposit.

Almadén is by far the largest deposit of the district but not the only one of economic relevance. Other important deposits hosted by the Criadero Quartzite include those of El Entredicho and La Nueva Concepción, Las Cuevas formed in the Upper Silurian whereas minor deposits such as Corchuelo and Guadalperal are found in the Devonian (Fig. 1). The Variscan deformations resulted in the folding of the deposits and even remobilization of cinnabar in those affected by late shear zones, such as Las Cuevas where cinnabar is also found in tension gashes in the country rocks. Hydrothermal alteration in the volcanic rocks of the Almadén syncline is characterized by the extensive development of $\mathrm{Ca}$ $\mathrm{Mg}-\mathrm{Fe}$ carbonates, chlorite and quartz defining the so-called 'regional alteration'. Chlorite, prehnite, pumpellyite, epidote, and actinolite are also observed, although they are restricted to isolated bodies of quartzdiabase in upper part of the stratigraphic column (Higueras et al., 1995).

\section{Magmatic rocks}

\subsection{Rock types}

A variety of magmatic rocks are recognized at the Almadén syncline. These differ in petrography, geochemical signatures (to be discussed later) and emplacement styles. The magmatism spanned from Ordovician to Devonian, and key petrographic features are the following (Higueras, 1995):

- Diatremes of basaltic composition with a matrix of lapilli tuffs (the so-called Frailesca rocks), composed of completely altered olivinebasalt clasts, and sedimentary clasts. The Frailesca (or Friars-like) rock receives its name after its textural similarity to the patchy aspect of the robes of the early Franciscan monks.

- Porphyritic lavas, ranging in composition from basanites and nephelinites to rhyolites, through olivine-basalts, pyroxenitic-basalts (pyroxene cumulates), trachybasalts, trachytes, and very scarce rhyolites. Basanites, nephelinites and olivine basalts are the main petrographic types, whereas the intermediate and felsic members are much less abundant. Minerals in these rocks comprise olivine phenocrysts; diopsidic pyroxene as phenocrysts and matrix; analcite as phenocrysts and matrix; plagioclase (microlites in the less differentiated, phenocrysts and matrix in intermediate and felsic varieties); biotite phenocrystals in intermediate rocks; and K-feldspar and quartz as phenocrysts and matrix of the felsic rocks. Late magmatic kaersutitic amphibole and Ti-rich biotite are also conspicuous in the mafic types. Textures are porphyric, with a crystalline matrix, and often vesicular. These rocks crop out as horizons of variable thickness interbedded with the detrital sequences, and in places can be also recognized as sills.

- Subvolcanic mafic rocks with doleritic texture, which allows classification as diabases. Major minerals are augitic pyroxene and calcic plagioclase. Minor minerals are olivine as small phenocrysts in olivine diabases, and alkaline feldspar and quartz (interstitial or in graphic intergrowths) in quartz-diabases. Olivine diabases are fine grained and outcrop as sills of metric scale thickness, almost indistinguishable from the porphyritic varieties, whereas the quartz-diabases are medium grained and outcrop as small stocks, and sills up to $5 \mathrm{~m}$ thick.

- Ultramafic fragments that occur as clasts in the Frailesca rocks and as xenoliths in the least differentiated basalts. They contain $50-80 \%$ olivine, pyroxene, and minor spinel, usually unaltered, which allows their classification as spinel lherzolites. These are key pieces of the
Almadén geologic history because given that the upper mantle cannot be investigated by direct sampling, it follows that peridotite xenoliths hosted in basaltic rocks provide a powerful insight to define its main petrological features (e.g., Gasperini et al., 2006).

The distribution of the different volcanic rock types in the stratigraphic column shows some remarkable features (Fig. 1). For example, only the Frailesca type rocks crop out in the Ordovician sequence, whereas in the Silurian and Lower Devonian both Frailesca type rocks and basaltic lavas are very common. On the other hand, the Upper Devonian is characterized by the common presence of trachytes, whereas the uppermost Devonian (Upper Frasnian) comprises the full spectra of magmatic rocks, thus revealing a complex magmatic evolution throughout time in the Palaeozoic basin hosting the Almadén district. All sedimentation and mafic magmatism ended in late Devonian time with the onset of the Variscan compressions in central Iberia (e.g., Doblas et al., 1994).

\subsection{Whole-rock geochemistry and magmatic source}

Thirty four samples comprising the different rock types with the least possible alteration were selected for whole-rock analyses (Table 1) (Higueras, 1995). High Ni and $\mathrm{Cr}$ contents for basanites, olivine basalts, olivine diabases and pyroxene basalt, as well as their high $[m g](\mathrm{MgO} /(\mathrm{MgO}+\mathrm{FeO}))$ numbers suggest that they were derived from primitive, mantle-derived magmas. Most of the magmatic rocks plot in the alkali basalts and basanite/nephelinite fields and correspond to an intraplate setting (Fig. 2). The primitive mantle normalized spider diagrams show the major differences found between these rocks.

Table 1

Mean results for major and trace elements from magmatic rocks from Almadén. LOI: loss on ignition, $\mathrm{n}$ : number of analyses, $[\mathrm{mg}]$ : $\mathrm{MgO} / \mathrm{MgO}+\mathrm{FeO}$. Data from Higueras (1995).

\begin{tabular}{|c|c|c|c|c|c|c|}
\hline & Basanites & $\begin{array}{l}\text { Olivinine } \\
\text { basalts }\end{array}$ & $\begin{array}{l}\text { Piroxene } \\
\text { basalts }\end{array}$ & Trachybasalts & $\begin{array}{l}\text { Olivine } \\
\text { diabases }\end{array}$ & $\begin{array}{l}\text { Quartz } \\
\text { diabases }\end{array}$ \\
\hline$n$ & 8 & 6 & 4 & 3 & 8 & 5 \\
\hline $\mathrm{SiO}_{2}$ & 38.01 & 44.44 & 39.18 & 49.32 & 43.57 & 50.65 \\
\hline $\mathrm{Al}_{2} \mathrm{O}_{3}$ & 9.84 & 14.22 & 12.12 & 14.69 & 13.70 & 14.29 \\
\hline $\mathrm{Fe}_{2} \mathrm{O}_{3}$ & 1.78 & 1.39 & 1.85 & 1.47 & 1.66 & 1.50 \\
\hline $\mathrm{FeO}$ & 10.67 & 9.96 & 11.11 & 7.80 & 10.13 & 8.00 \\
\hline $\mathrm{MnO}$ & 0.19 & 0.16 & 0.25 & 0.14 & 0.17 & 0.19 \\
\hline $\mathrm{MgO}$ & 12.70 & 9.07 & 11.86 & 5.21 & 9.38 & 5.99 \\
\hline $\mathrm{CaO}$ & 11.11 & 6.83 & 10.16 & 6.84 & 7.52 & 8.22 \\
\hline $\mathrm{K}_{2} \mathrm{O}$ & 0.79 & 0.80 & 0.61 & 1.02 & 0.67 & 0.54 \\
\hline $\mathrm{Na}_{2} \mathrm{O}$ & 1.31 & 1.64 & 1.60 & 3.69 & 1.88 & 3.16 \\
\hline $\mathrm{TiO}_{2}$ & 2.86 & 2.58 & 2.98 & 2.29 & 2.35 & 1.80 \\
\hline $\mathrm{P}_{2} \mathrm{O}_{5}$ & 0.65 & 0.37 & 0.71 & 0.43 & 0.44 & 0.20 \\
\hline LOI & 9.02 & 7.81 & 6.90 & 5.43 & 7.39 & 3.78 \\
\hline$\Sigma$ & 100.10 & 100.16 & 100.56 & 98.95 & 99.87 & 99.06 \\
\hline $\mathrm{CO}_{2}$ & 6.01 & 3.24 & 3.48 & 3.24 & 3.39 & 0.93 \\
\hline $\mathrm{H}_{2} \mathrm{O}+$ & 3.04 & 4.09 & 3.29 & 2.18 & 3.92 & 2.93 \\
\hline $\mathrm{Cr}$ & 340.00 & 443.67 & & 146.00 & 414.25 & 185.50 \\
\hline $\mathrm{Ni}$ & 263.63 & 196.17 & 257.50 & 91.33 & 147.63 & 61.60 \\
\hline Co & 63.00 & 51.00 & 53.50 & 33.00 & 44.57 & 39.50 \\
\hline Sc & 18.42 & 25.40 & 20.50 & & 23.65 & 20.80 \\
\hline V & 217.00 & 193.00 & 239.50 & 136.00 & 213.57 & 158.00 \\
\hline $\mathrm{Cu}$ & 58.58 & 46.43 & 62.00 & 27.00 & 58.49 & 57.60 \\
\hline $\mathrm{Pb}$ & 6.38 & 11.17 & 7.00 & 4.67 & 5.25 & 4.40 \\
\hline $\mathrm{Zn}$ & 107.67 & 89.53 & 93.50 & 158.00 & 88.60 & 80.50 \\
\hline $\mathrm{Rb}$ & 33.33 & 2.50 & 24.00 & & 23.00 & 14.00 \\
\hline $\mathrm{Ba}$ & 1478.50 & 437.00 & 715.00 & 198.00 & 1144.43 & 305.00 \\
\hline $\mathrm{Sr}$ & 939.83 & 469.50 & 738.00 & & 612.33 & 409.00 \\
\hline $\mathrm{Nb}$ & 68.25 & 47.17 & 66.00 & 51.33 & 54.50 & 17.40 \\
\hline $\mathrm{Zr}$ & 235.13 & 198.00 & 287.50 & 312.33 & 197.50 & 97.60 \\
\hline $\mathrm{Y}$ & 23.63 & 23.67 & 27.00 & 27.67 & 19.63 & 17.00 \\
\hline Th & 5.46 & 3.00 & 4.50 & 4.15 & 3.45 & 1.65 \\
\hline U & 1.68 & 1.10 & 1.40 & 1.40 & 1.33 & 0.40 \\
\hline $\mathrm{La}$ & 61.08 & 31.40 & 51.45 & 35.85 & 35.25 & 12.50 \\
\hline $\mathrm{Lu}$ & 0.24 & 0.23 & 0.27 & 0.28 & 0.23 & 0.19 \\
\hline$[m g]$ & 0.68 & 0.62 & 0.66 & 0.54 & 0.62 & 0.57 \\
\hline
\end{tabular}


Alkaline porphyritic rocks (basanites/nephelinites, olivine basalts and trachybasalts) show similar patterns. Major differences between the alkaline and the transition to tholeiitic rocks are related to the presence of a positive $\mathrm{Nb}$ anomaly, higher $\mathrm{TiO}_{2}$ and HFSE contents, and higher LREE/HREE ratios for the alkaline rocks (Fig. 3A). All these geochemical characteristics are indicative of continental intraplate magmas that eventually yielded basalts (s.l.) and olivine diabases of alkaline affinity, and quartz-diabases of transitional to tholeiitic affinity (Higueras, 1995). Other conspicuous feature of the Almadén mafic magmatism is its high content in $\mathrm{CO}_{2}$. Most of the mafic volcanic rocks display high concentrations of $\mathrm{CO}_{2}$ ranging from 8 to $15 \%$, while in and around the mercury deposits, these figures can be as high as 20 and $30 \%$ in basalts and ultramafic xenoliths respectively (Higueras, 1995). The isotopic composition of these carbonates at about -6\% (Eichmann et al., 1977; Rytuba et al., 1989) suggests a primary and probably a mantle origin for this component. The recent work of Helo et al. (2011) for Mid Ocean Ridge basalts provides some useful insights into this matter. These authors indicate that given its low solubility, $\mathrm{CO}_{2}$ is the only magmatic volatile phase that undergoes significant exsolution as the basaltic magmas ascend to the sea floor; there $\mathrm{CO}_{2}$ may trigger explosive eruptions and widespread pyroclastic deposits. These findings would further explain the explosive nature of volcanism at Almadén as shown by the numerous Frailesca rock units and pyroclastic rocks along the stratigraphic column.

The geochemical and mineralogical data suggest that the Almadén mafic magmas had an upper mantle origin, and were then extruded and/or emplaced in a continental intraplate setting, evolving from

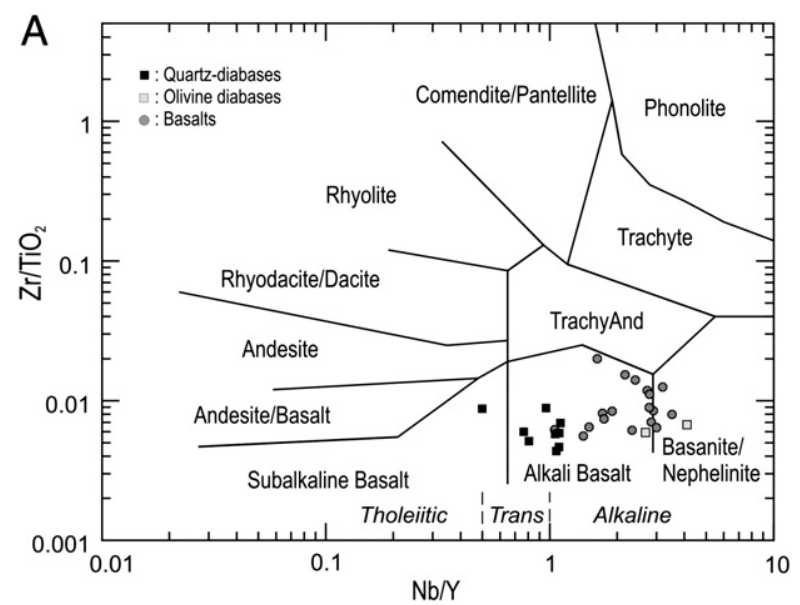

B

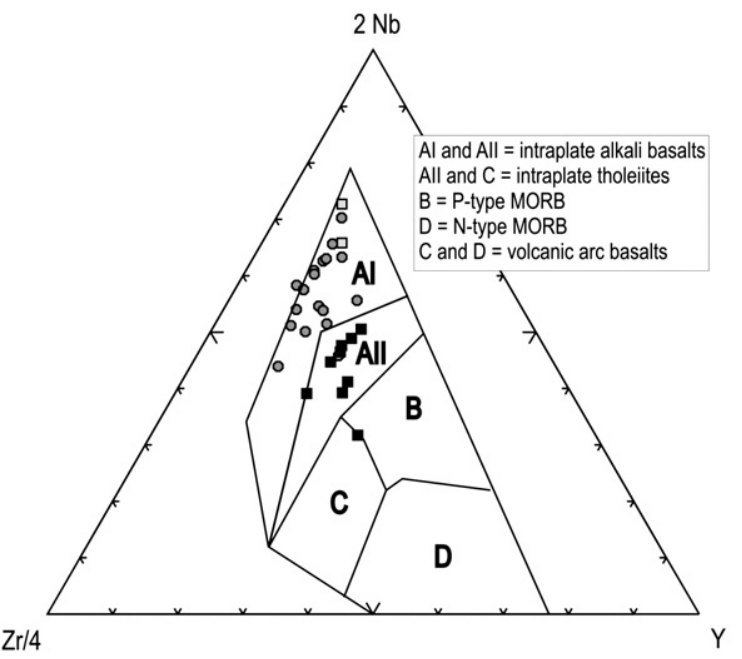

Fig. 2. A: Whole rock trace-element plot of Winchester and Floyd (1977) for the classification of volcanic rocks. Boundaries between tholeiitic-transitional-alkaline after Pearce (1982). B: Whole rock trace-element plot of Meschede (1986) for the tectonic setting of volcanic rocks.
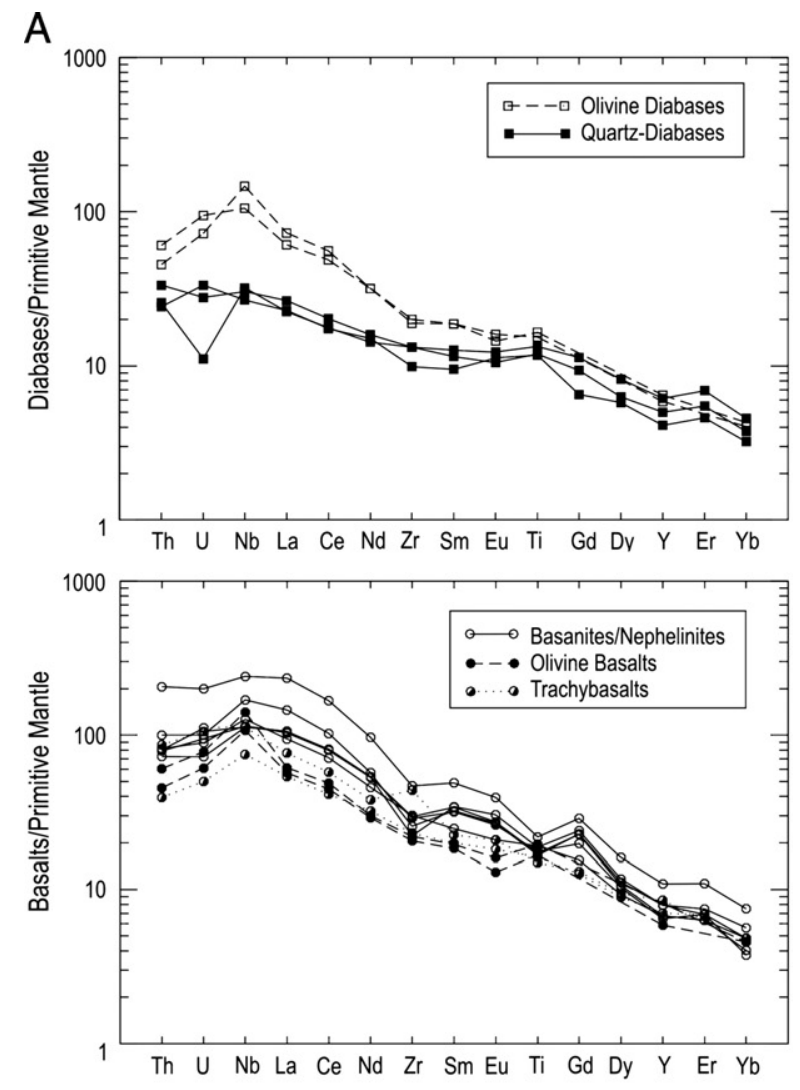

B

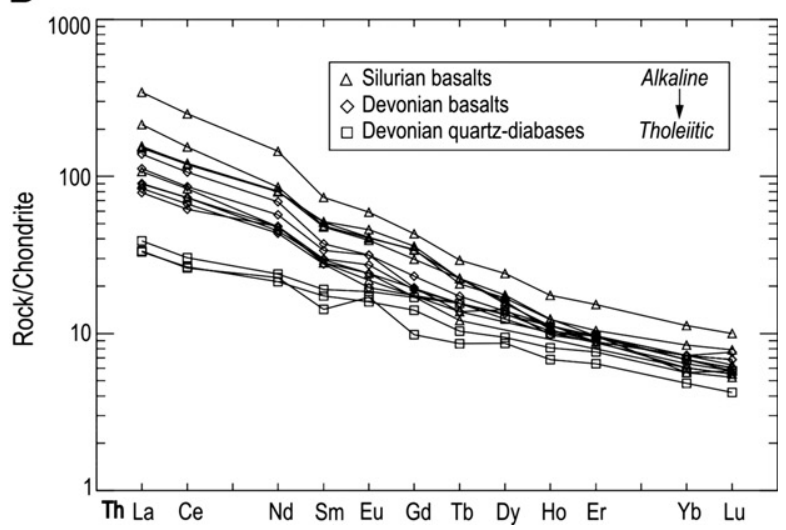

Fig. 3. A: Primitive mantle normalized spider diagrams for subvolcanic rocks (above), and lavas (below); normalization values after Taylor and McLennan (1985). B: Chondrite normalized spider diagrams for mafic rocks of the Almadén syncline.

alkaline basaltic lavas and olivine diabases to quartz-diabases of transitional tholeiitic affinity. The $\mathrm{K} / \mathrm{P}$ and $\mathrm{Nb} / \mathrm{U}$ ratios, coupled to the absence of a negative $\mathrm{Nb}$ anomaly, rule out a crustal component in the generation of the Almadén mafic magmas (Cox and Hawkesworth, 1984; Hart et al., 1989; Hoffman et al., 1986). The Zr/Nb (3.45-6.08) and Zr/Y (5.74-11.29) ratios are similar to those of mafic rocks originating from enriched mantle sources. La/Nb ratios lower than 1 for the Almadén mafic rocks suggest that they may have been derived from an asthenospheric source (Fitton et al., 1988). Other trace element ratios, such as Th/La (0.09 to 0.13 ), $\mathrm{Th} / \mathrm{Nb}$ (0.06 to 0.08 ), and $\mathrm{Ba} / \mathrm{Nb}$ (3.86 to 21.66), are similar to those of an enriched mantle source (Wilson, 1993). Besides, this interpretation is further supported by Hf-isotope signatures suggesting the involvement of enriched mantle components for the origin of the Variscan gabbros from the Central Iberian Zone (Villaseca et al., 2011). This enriched mantle signature might not be an isolated feature restricted to the Central Iberian Zone, because as shown by Sm-Nd data, basalts 
from other sectors of the Gondwanan margin show equivalent signatures (Brendan Murphy et al., 2008). Evolution from basanite dominant mafic members in the Silurian to trachybasaltic, trachytic and even rhyolitic magmas in the Upper Devonian is a conspicuous indicator of the geochemical evolution of the Almaden magmas. The LREE/HREE ratios show evidence of a decreasing evolution from the Silurian rocks, through Devonian to the intrusive quartz-diabases (Fig. 3B). According to White and McKenzie (1995), this pattern is indicative of decrease in the depth of generation, which could be from about $100 \mathrm{~km}$ for the Silurian rocks to $60 \mathrm{~km}$ for the tholeiitic quartz-diabases. These estimated depths are in agreement with the presence of spinel lherzolites as xenoliths in the Silurian basaltic lavas.

\section{Discussion and conclusions}

\subsection{Hydrothermal processes}

Eichmann et al. (1977), and Saupé and Arnold (1992) reported the results of extensive research on the carbon, oxygen and sulfur isotope geochemistry of the country rocks and ores from the Almadén $\mathrm{Hg}$ deposits. Eichmann et al. (1977) proposed a primary mantle source for the carbonate constituents in the metavolcanics, whereas Saupé and Arnold (1992) suggested that the Ordovician shales were the main source of carbon and sulfur.

On the basis of the most frequent mineral assemblages in the Almadén volcanic rocks (albite-chlorite-carbonate-quartz \pm epidotepyrite \pm titanium-iron oxides), the dominant conditions for the regional alteration can be estimated at $200-300{ }^{\circ} \mathrm{C}, \mathrm{pH}$ from near to neutrality to alkaline, and $\mathrm{fO}_{2}$ close to the magnetite-pyrite stability boundary (Ellis, 1979; Hemley et al., 1971; Ohmoto and Goldhaber, 1997). These temperatures are in agreement with those measured for equivalent mineral assemblages in presently active geothermal fields, such as that of Reykjanes in Iceland (Yardley, 1989), in the range of $100-300{ }^{\circ} \mathrm{C}$. Besides, the albite-chlorite-carbonate-quartz alteration assemblage is also typical of the Canadian type Archean lode gold deposits (e.g., Dubé and Gosselin, 2007) in both their mafic and ultramafic rock units. Specific thermal data for carbonate alteration (plus quartz, chlorite, albite) in this type of deposits is provided by the comprehensive work of Kishida and Kerrich (1987) on oxygen isotope temperatures for gold mineralization at the Kerr-Addison mine, which indicates that temperatures are consistently in the range of $200-300{ }^{\circ} \mathrm{C}$.

Oxygen isotope compositions reported by Eichmann et al. (1977) range from $+12.8 \%$ o to $+19.9 \%$ o (versus SMOW) for carbonates in mafic lavas and from $+14.0 \%$ o to $+18.9 \%$ ofor carbonates in mineralized veins and the Frailesca rocks. The study of the $\delta^{18} \mathrm{O}$ values for hydrothermal fluids in the Almadén case is difficult because the variable carbonate mineralogy (Eichmann et al., 1977), and by the well known susceptibility of carbonates to oxygen isotopic re-equilibration at low temperatures (O'Neil,, 1987). Carbonates in active geothermal systems may achieve isotopic equilibrium with fluids down to temperatures as low as $150{ }^{\circ} \mathrm{C}$. Below this temperature the solute species $\mathrm{H}_{2} \mathrm{CO}_{3}$ is depleted in ${ }^{13} \mathrm{C} \%$ o with respect to calcite (e.g., Robinson, 1974); besides, this temperature seems reasonable taking into account the mineral assemblage (see above) and a waning hydrothermal system, thus closer to $100^{\circ}$ than $300{ }^{\circ} \mathrm{C}$ (during re-equilibration).

Thus we can use this value as a reference in our $\delta^{18} \mathrm{O}_{\text {fluid }}$ estimates. Depending on the pertinent carbonate-fluid equilibrium, the $\delta^{18} \mathrm{O}$ values for the Almadén hydrothermal fluids are estimated to have ranged either from $+0.6 \%$ o to $+7.7 \%$ o if coexisting with calcite/ankerite (Mumin et al., 1996), or from $-1.0 \%$ o to $+6.0 \%$ o if coexisting with dolomite (Mathews and Katz, 1977). The range of estimated $\delta^{18} \mathrm{O}_{\text {fluid }}$ values is a characteristic of both modern and fossil submarine hydrothermal systems (Bowers and Taylor, 1985; Munhá et al., 1986), where geothermal waters of marine origin $\left(\delta^{18} \mathrm{O}_{\text {seawater }}=0 \pm 1 \%\right.$; Knauth and Lowe, 1978; Shepard, 1986) commonly undergo positive oxygen isotope shifts to higher $\delta^{18} \mathrm{O}$ values, due to oxygen isotope exchange reactions with ${ }^{18} \mathrm{O}$-rich host rocks. Close correspondence between estimated and observed $\delta^{18} \mathrm{O}_{\text {fluid }}$ values strongly supports the hypothesis that hydrothermal activity in the Almadén basin was favored by the interaction of basaltic rocks with seawater.

The carbon isotope compositions of Almadén hydrothermal carbonates (Eichmann et al., 1977) range from $-3.6 \%$ o to $-9.0 \%$ o (vs. PDB) $\quad\left(-9.0 \% \circ<\delta^{13} \mathrm{C}_{\text {mafic }}\right.$ metavolcanics $<-3.6 \%$; $-8.6 \%$ $<\delta^{13} C_{\text {mineralized veins/fragmental volcanics }}<-3.9 \%$ o), which are similar to $\delta^{13} \mathrm{C}$ values measured on aqueous $\mathrm{CO}_{2}$ and calcite from modern, submarine hydrothermal systems (e.g., Bowers and Taylor, 1985; Stakes and O'Neil, 1982). Exclusive derivation of $\mathrm{CO}_{2}$ from organic matter in the Ordovician black shales $\left(\delta^{13} C_{\text {"organic" }} \approx-30 \%\right.$; Eichmann et al., 1977) as suggested by Saupé and Arnold (1992) seems unlikely. Low temperature maturation of organic matter yields $\delta{ }^{13} \mathrm{C}_{\mathrm{CO} 2} \approx \delta^{13} \mathrm{C}_{\text {organic-c }}$ (e.g., Arneth and Matzigkeit, 1986), which is much lighter than that inferred for equilibrium with hydrothermal carbonates. On the other hand, the hydrolysis of reduced carbon would imply $\delta{ }^{13} \mathrm{C}_{\mathrm{H} 2 \mathrm{CO} 3}-\delta^{13} \mathrm{C}_{\mathrm{\Sigma C}} \approx+21 \%$ 。 $+26 \%$, requiring almost invariant highly reduced conditions of carbonate deposition (e.g., Ohmoto, 1972). As discussed above, this is quite unlikely for the Almadén hydrothermal system. At a specified $\left(\mathrm{T}, \mathrm{pH}, \mathrm{fO}_{2}\right)$ range of conditions, the observed $\delta^{13} \mathrm{C}$ values, together with the lack of correlation between $\delta^{18} \mathrm{O}$ and $\delta^{13} \mathrm{C}$, favor multiple carbon sources for the hydrothermal carbonates in the Almadén deposits. Considering the $\mathrm{CO}_{2}$-rich mantle source, the undersaturated character of the magmas that gave rise to the Almadén mafic volcanics (Higueras, 1995), and the analogy with modern, submarine hydrothermal systems, it seems hard to escape the conciliatory hypothesis that, besides seawater $\left(\delta^{13} C_{\text {marine }} \approx-2 \%\right.$; Saltzman, 2002) both mantle $\left(\delta^{13} C_{\text {mantle }} \approx-5 \%\right.$; e.g., Deines, 2002$)$ and organic sedimentary carbon sources $\left(\delta^{13} C_{\text {organic }} \approx-30 \%\right.$; Eichmann et al., 1977) were contributors to the hydrothermal carbonates in Almadén.

Besides, this is the least one might expect in a submarine hydrothermal system triggered by volcanic activity, and the same can be said for sulfur on what multiple sources is concerned. The sulfur isotopic compositions reported by Rytuba et al. (1989), Saupé and Arnold (1992), Jébrak et al. (1997) and Higueras et al. (1999b) for the Almadén ore minerals and country rocks show a wide range of variation. Cinnabar displays a wide overall range of $\delta^{34} S$ values, from $-1.6 \%$ o to $+9.0 \%$. Particularly significant to the discussion is the positive correlation between sulfur contents and $\delta^{34} \mathrm{~S}$ values $(+1.0 \%$ o- $+6.8 \%$ o), reported by Saupé and Arnold (1992) for the Almadén volcanic rocks. Although the linear $\delta^{34} \mathrm{~S}-\mathrm{S}$ relationship suggests an external source of constant composition (and, consequently, constant physical/chemical conditions of basalt/seawater interaction), probably this was not the case. Within the hydrothermal system, water-rock interactions should have proceeded under a wide range of temperatures, $\mathrm{pH}, \mathrm{fO}_{2}$, and water/rock ratios, reflecting the variable lithological permeabilities at different sites of the fluid convection cells. Thus, a much wider range of S contents (e.g., Higueras et al., 1999b; Saupé, 1990), $\delta^{34}$ S enrichment/depletion and variable $\delta^{34} \mathrm{~S}-\mathrm{S}$ trends (e.g., Saupé and Arnold, 1992) must be expected for the Almadén basalts. At the conditions specified above for $\mathrm{Hg}$ sulfide deposition, $\delta^{34} S_{\mathrm{H} 2 \mathrm{~S}}$ must have been close to $\delta^{34} \mathrm{~S}_{\mathrm{SS} \text {-fluid }}$ (Ohmoto, 1972). Thus, the range of cinnabar $\delta^{34} \mathrm{~S}$ values could also reflect variable source compositions.

Leaching of sulfur from the volcanic rocks by geothermal waters provides an indirect mechanism for incorporating variable proportions of magmatic and seawater sulfur into the mineralizing fluids, contributing (along with fractionation and physical chemical variations) to the variable isotopic compositions of $\mathrm{Hg}$ sulfides. Sulfate can be converted to sulfide by organic matter-mediated sulfate reduction either by bacterial activity (bacterial sulfate reduction, Jannasch, 1989) or by an abiological reaction (thermochemical sulfate reduction; Machel, 2001). Given that seawater sulfur is isotopically heavier $\left(\delta^{34} S \approx+27 \%\right.$; Kampschulte and Strauss, 2004) than that of the country rocks, then reduction of seawater sulfate to sulfide would thus produce a heavier $\delta^{34} \mathrm{~S}$ signature in the ore (e.g., Bickle et al., 
1994). In contrast, hydrogen sulfide derived from the dissolution of biogenic sulfides in sedimentary rocks would be expected to have negative $\delta^{34} \mathrm{~S}$ (Seal, 2006).

The leaching of sulfur from the volcanic rocks by geothermal waters provides an indirect mechanism for incorporating variable proportions of magmatic and seawater sulfur into the mineralizing fluids, explaining the variable isotopic compositions of $\mathrm{Hg}$ sulfides. On the other hand, lead isotopic data for cinnabar (Higueras et al., 2005) show that the bulk of the lead data defines a steep array trend on the ${ }^{207} \mathrm{~Pb} /{ }^{204} \mathrm{~Pb}-{ }^{206} \mathrm{~Pb} /{ }^{204} \mathrm{~Pb}$ diagram and suggests a significant contribution of sedimentary $\mathrm{Pb}$ for the ores of the Almadén $\mathrm{Hg}$ deposits, although other minor contributions from a less radiogenic reservoir (e.g. magmatic) cannot be ruled out. A multiple source of lead is common in seafloor hydrothermal systems, including both magmatic and sedimentary reservoirs. The latter may be the major source of $\mathrm{Pb}$, representing a large detrital input of upper crustal material (Halbach et al., 1997). In this respect, a major issue regarding mercury in hydrothermal systems is that its behavior departs from that of other metals likely to form sulfides (such as $\mathrm{Pb}$ ). As indicated in the comprehensive work of Varekamp and Buseck (1984a), different from other metals $(\mathrm{M})$ that will form $\mathrm{M}-\mathrm{S}$ complexes, the abundance of $\mathrm{Hg}^{0}$ vap in geothermal emissions suggests that $\mathrm{Hg}^{\mathrm{O}}$ aq is the dominant species. Furthermore, as discussed by these authors, the contributions of $\mathrm{Hg}-\mathrm{Cl}, \mathrm{Hg}-\mathrm{S}, \mathrm{Hg}-\mathrm{CO}_{3}$, and $\mathrm{Hg}-\mathrm{OH}$ are apparently unimportant for $\mathrm{Hg}$ transport in dilute systems. $\mathrm{Hg}$ deposition may then occur in response to mixing with either oxidizing or acidic water, turning $\mathrm{Hg}^{0}{ }_{\mathrm{aq}}$, into $\mathrm{Hg}^{2+}$ :

$\mathrm{Hg}_{\mathrm{aq}}^{0}+1 / 2 \mathrm{O}_{2}+2 \mathrm{H}^{+} \rightarrow \mathrm{Hg}^{2+}+\mathrm{H}_{2} \mathrm{O}$.

Subsequent cinnabar deposition may follow if sulfur is available in the system, although this mineral is unstable in a vapor-dominated system (Varekamp and Buseck, 1984a):

$\mathrm{HgS}_{\mathrm{s}} \rightarrow \mathrm{Hg}_{\text {gas }}^{0}+1 / 2 \mathrm{~S}_{2 \mathrm{gas}}$.

Thus, given the highly volatile character of mercury, the path to ore deposition can be entirely different to that of lead (or even sulfur), and as such, it would be unwise to mix up the sources of one and the other. In very simple terms: the fact that two objects are found side by side does not necessarily imply that they 'came together' to that particular site. This is particularly relevant to the case of open hydrothermal systems, in which the solutions can be leaching metals from entirely different sources such as older sedimentary rocks and the volcanic units that actually triggered the system.

\subsection{On the origin of mercury}

Derivation of the Almadén $\mathrm{Hg}$ from sediments (e.g., Ordovician black shales) has been advocated by Saupé (1990) and Saupé and Arnold (1992), who also refuted a mantle origin. Saupé in his classic work of 1990 stated that a positive mercury anomaly of the mantle below Almaden left unanswered a double question: why should such an anomaly be so limited in space (Almadén) and in time (Silurian)? We can answer both questions but let us first take into account a piece of the puzzle that perhaps has not received all the required attention: the clasts and xenoliths of spinel lherzolites that are found in the Frailesca rocks and basalts respectively, which definitively connects the Almadén mafic magmatism to the mantle. In this regard, intraplate magmatism does not necessarily involve the formation of huge igneous provinces but whatever its size and volume, it is centered in an area. A wonderful example is provided by the tiny Cenozoic Calatrava Volcanic Province (not far away from Almadén), which is characterized by an intraplate alkaline undersaturated magmatic suite including melilitites, nephelinites, alkali olivine basalts and leucitites (López-Ruiz et al., 1993). This low-volume-type of magmatism would explain the first of Saupé's (1990) questions regarding the limited area of influence of the Almadén magmatism. Although the geochemical data could be interpreted in terms of a mantle plume, the small area affected by the Almadén magmatism makes unlikely a large mantle upwelling from any great depth. Instead, similar to the case of Calatrava (López-Ruiz et al., 1993), a localized diapiric instability within the upper asthenosphere at about $100 \mathrm{~km}$ can perfectly account for the Almadén magmatism. Second, regarding the time-limited influence of the Almadén magmatism, we should take two facts into account: 1) a Silurian to Devonian time span can be hardly regarded as 'short' (and even less considering that the first Frailescas appeared in the Ordovician); 2) although most of the mercury was deposited during Early Silurian time, the process continued well into the Devonian. In this regard, waning metallogenic activity is the least we would expect within an evolving magmatic scenario such that of Almadén. Indeed, except for a possible contribution to the carbon budget, the isotope data reviewed here do not require any significant involvement of the sedimentary reservoir in the hydrothermal processes related to $\mathrm{Hg}$ mineralization. This is further supported by ${ }^{40} \mathrm{Ar} /{ }^{39} \mathrm{Ar}$ encapsulated dating on illite and $\mathrm{Cr}$-rich micas associated with mercury mineralization, suggesting an ore deposition time span between the deposition of the Criadero Quartzite and the later episode of mineralization. After these radiometric ages, mineralization started at least by the mid to lower Silurian (Hall et al., 1997).

Illite is associated with a later stage of $\mathrm{Hg}$ mineralization (cinnabar + kaolinite + pyrophyllite + chlorite) which locally replaces an earlier episode associated with carbonates and $\mathrm{Cr}$-mica (Morata et al., 2001). The dating results from illite separates suggest that the later stages of $\mathrm{Hg}$ mineralization or remobilization occurred about $360 \mathrm{Ma}$, which is about 20 Ma younger than any mercury-hosting rocks in the district and coincides with the onset of regional deformation during the Hercynian orogeny. $\mathrm{Cr}$-mica ages are variable and range from 365 Ma to 427 Ma.

The huge, unique, Almadén $\mathrm{Hg}$ deposits should have required exceptional conditions for their genesis. We suggest that such a world-class geochemical anomaly should ultimately reflect the characteristics of the mantle source for the alkaline basaltic magmas; indeed, mantle metasomatic activity and the low degrees of partial melting inherent to the genesis of the Almadén mafic magmas (Higueras and Munhá, 1993) could have converged to provide an efficient mechanism for $\mathrm{Hg}$ pre-enrichment in the basaltic rocks (Dromgoole and Pasteris, 1987). In this regard, several mercury deposits around the world have shown some unexplained connections with mantle metasomatism (Borisenko et al., 2005). However, the mercury content of the mantle and the likelihood of magmatic concentration remain poorly constrained. Isotopic evidence from the study on ${ }^{3} \mathrm{He} /{ }^{4} \mathrm{He}$ ratios in fluid inclusions from mercury deposits suggest that a mantle origin of $\mathrm{Hg}$ ore-forming systems is likely to have occurred in some deposits (Borisenko et al., 2005). However, mantle degassing of primordial ${ }^{3} \mathrm{He}$ may be a much more complex phenomenon than initially thought as in fact mantle helium evolution does not require the existence of a primordial, undegased high ${ }^{3} \mathrm{He} /{ }^{4} \mathrm{He}$ reservoir (Class and Goldstein, 2005).

Whatever the case, and beyond the nuances of ${ }^{3} \mathrm{He} /{ }^{4} \mathrm{He}$ isotope geochemistry, the volcanic activity releases huge amounts of metals into the atmosphere via quiescent degassing (Krabbenhoft and Schuster, 2002; Nriagu and Becker, 2003; Oppenheimer, 2004; Oyarzun et al., 2005). In the case of mercury, a highly volatile element, quiescent degassing would account for $10 \%$ of the yearly estimated flux: small eruptions may contribute about $75 \%$ of the total, whereas those of catastrophic character would overwhelm the atmospheric budget of the element (Pyle and Mather, 2003). Furthermore, the well known faunal mass extinction of Late Permian time has been recently related to massive mercury degassing during formation of the Siberian Traps (Sanei et al., 2012), a volcanic province that completely formed in a 
just about $1 \mathrm{Ma}$. This is a short time span that nevertheless resulted in the extrusion of about 2-3 millions of cubic kilometers of volcanic rocks (Renne et al., 1995). Thus, that volcanic activity (in general), and mantle derived intraplate volcanism (specifically) can transport and release mercury in great amounts should therefore be beyond dispute. For example during the first two weeks of September 1980 the daily $\mathrm{Hg}$ output from the Mt St Helens system (during a non-eruptive phase) ranged from 200 to $1700 \mathrm{~kg}$ (Varekamp and Buseck, 1981).

On the other hand, neither alkaline intraplate nor tholeiitic ocean ridge basalts appear to be particularly enriched in mercury, showing a range of 2 to $9 \mathrm{ppb} \mathrm{Hg}$ (Coderre and Steinhorsson, 1977). These authors argue that mercury is either distilled into a gas phase such as $\mathrm{CO}_{2}$ before or during the eruption, or the magmas never contained mercury in excess of the observed low concentrations because the source area is continuously degassing, thus becoming Hg-depleted. This assertion is somehow supported by the fact that magmatic vapors are usually enriched in mercury, and a common component of these vapors is magmatic $\mathrm{CO}_{2}$ (Varekamp and Buseck, 1984b). In this regard, mercury is not only efficiently transported and discharged to the atmosphere by the volcanism, because degasification can also lead to the formation of economic mineralization. This is the case of Mount Amiata in Italy, where Plio-Pleistocene volcanism is related to a deep seated magmatic source with crustal and mantle components (Wilson, 1989). There the $\mathrm{CO}_{2}$-rich geothermal activity triggered by this volcanism resulted in $\mathrm{Hg}$-( $\mathrm{Sb}-\mathrm{Au})$ ore deposit formation (e.g., Morteani et al., 2011).

At this point we should take into consideration the widespread, pervasive alteration to carbonates in the Almadén rocks. As explained above, the volcanic rocks have $\mathrm{CO}_{2}$ concentrations ranging from 0.93 to $6.01 \%$ (Table 1 ), whereas in and around the mercury deposits these figures may be as high as $20-30 \%$ (Higueras, 1995), thus suggesting massive magma degasification. In this regard, as indicated by Varekamp and Buseck (1984b), key for the fate of mercury in a hydrothermal system are the conditions at which a $\mathrm{CO}_{2}$-rich phase is formed, that is, confining pressure, $\mathrm{CO}_{2}$ content of the fluid, and $\mathrm{pH}$ of the fluid. If any of these parameters is modified, distillation of mercury from the hot solution will follow. In this respect, an excellent example of the relationships and co-evolution of the $\mathrm{CO}_{2}$ phase and mercury may be provided by cinnabar grains visible in the center of millimeter-size carbonate-filled vesicles in the volcanic rocks of Almadén (Saupé, 1990).

Based on the data from Varekamp and Buseck (1981) for mercury output from quiescent degassing of the St Helens system, we may assume that the generation of $1000 \mathrm{~kg} \mathrm{Hg} /$ day would be a conservative figure for a scenario such as Almadén where volcanism was explosive. Given that Almadén had reserves in excess of 250,000 t $\mathrm{Hg}$, it follows that it would have taken some 700 years to infill the Criadero Quartzite with mercury. On the other hand, if most of the mercury (80\%) was lost to the ocean (Fig. 4) and only $200 \mathrm{~kg} \mathrm{Hg} /$ day went into de Criadero Quartzite, our figure jumps to about 3400 years, which is still well within the actual life span of a geothermal system. For example, the gold-rich Rotokawa field in New Zealand is at least 6000 years old (Krupp and Seward, 1987).

Thus, a volcanogenic origin for mercury, followed by distillation from a hot solution and transport, is not only plausible from the geothermal point of view (in a $\mathrm{CO}_{2}$-rich system such as that of Almadén) but additionally answers the question of why mercury was deposited in the Criadero Quartzite. This unit hosts an early (pre-cinnabar) framboidal pyrite and as shown by Coderre and Steinhorsson (1977), pyrite-rich horizons in geothermal fields may act as geochemical traps for mercury inducing precipitation.

\subsection{The search for a conceptual model}

At a larger scale a final question concerns the role of the Almadén Frailesca unit. As shown above, Frailesca type rocks were emplaced from Ordovician time onwards, but it is only at the base of the Silurian that huge $\mathrm{Hg}$ deposition took place (Fig. 1). No mercury deposits formed in the Ordovician, and those above the Lower Silurian are either small or insignificant (Fig. 1). So what makes the Lower Silurian so different? This period can be regarded as a transitional time span, between the scattered barren explosive volcanism (Ordovician) and the lava eruptions that began soon after the Criadero Quartzite was deposited. Thus, a connection between mercury deposition and volcanism goes beyond the mere existence of the latter, and poses additional doubts on a mercury source located at the Ordovician black shales. After all, if the 'recycling' case (Saupé, 1990) is based on mercury mobilization via explosive volcanic activity from sedimentary beds, why then no deposits formed precisely at the Ordovician where the putative $\mathrm{Hg}$ source was located? On the other hand, if we take into account that the Almadén syncline magmatism evolved in time, there is no reason to preclude a similar (although reversed) path for the metallogenic activity. In fact, as stated above, after Almadén and coeval deposits were formed, mercury deposition became less important in size (Fig. 1). We suggest that the passage from minor and scattered emplacements of Frailesca rocks in the Ordovician to a more consolidated volcanism (explosive and lava type) in the Silurian as the deep seated magma source evolved, marks a 'before and after' scenario in the Almadén syncline. Furthermore, we propose that this change may relate to major tectonic changes in the Iberian Massif, resulting in the isolation of the southern neighboring tectonic terrane (Ossa Morena), an event also marked by an abrupt change in magmatism during the late Ordovician - early Silurian transition (Simancas et al., 2004). In this regard, a profound change in the rheological conditions at the crustal and/or continental lithospheric scale was bound to have far reaching consequences on the magmatic activity. Some clues may be provided by the southern Ossa Morena, where after a stage of lower Paleozoic rifting, subduction took place in Silurian times resulting in crustal thickening, gravitational instability, and extensional shearing (Azor et al., 1994). This may have resulted further north in increasingly overpressurized magmas and therefore in the accumulation of volatile species in the deep magma chambers (Fig. 4). This is a key for our model for as early discussed for other metals, magmas that lose their volatile species will not form large ore deposits (or any at all) (e.g., Oyarzun et al., 2001; Oyarzun et al., 2003; Pasteris, 1996). As tectonic conditions evolved in the south (Azor et al., 1994) magmatism restarted but this time with a much larger $\mathrm{Hg}$ volatile fraction, a prerequisite for large deposition of mercury in the Lower Silurian. We propose that the deep seated magmas did not become Hg-depleted in a single (catastrophic) episode, but nonetheless no large deposits formed after the Lower Silurian (Fig. 1, 4). On one hand a large stock of Hg was lost in this episode, on the other, persistent volcanism must have led to a more continuous $\mathrm{Hg}$ degasification thus no large stocks were ever built up again after the Lower Silurian. This model somehow resembles that of Sibson (1990) for fluid pressure and earthquake ruptures along a fault zone (fluid-activated valve), only that in this case we are dealing with deep seated magmas (that progressively accumulated $\mathrm{Hg}^{0}$ gas) instead of fluids. However the outcome is relatively similar, with sudden outbursts that in the Almadén case resulted in magma degasification and ore deposit formation. That is what we call our "decreasing sawtooth wave model" (Fig. 4).

There is an additional matter to deal with, and that concerns the huge amount of mercury deposited at the Almadén deposit compared to other mineralized sites in the world. In this regard, most mercury deposits are very small and belong to the hot-spring type (Rytuba, 2004a,b), which from a geologic and thermodynamic perspective are shallow seated "open systems" (and as such, ready to outgas mercury), with many examples from Chile (e.g., Andacollo: $\mathrm{Cu}-\mathrm{Au}-\mathrm{Hg}$ ) (Oyarzun et al., 1996), Spain (e.g., Azogue Valley: Hg) (Viladevall et al., 1999), California (USA) (e.g., McLaughlin: Au-Hg) (Smith et al., 2008), and elsewhere. In this respect, we should bear in mind two facts: 1. Almadén is a "submarine" deposit, and as such it formed near to the sea floor under strong hydrostatic pressure conditions 


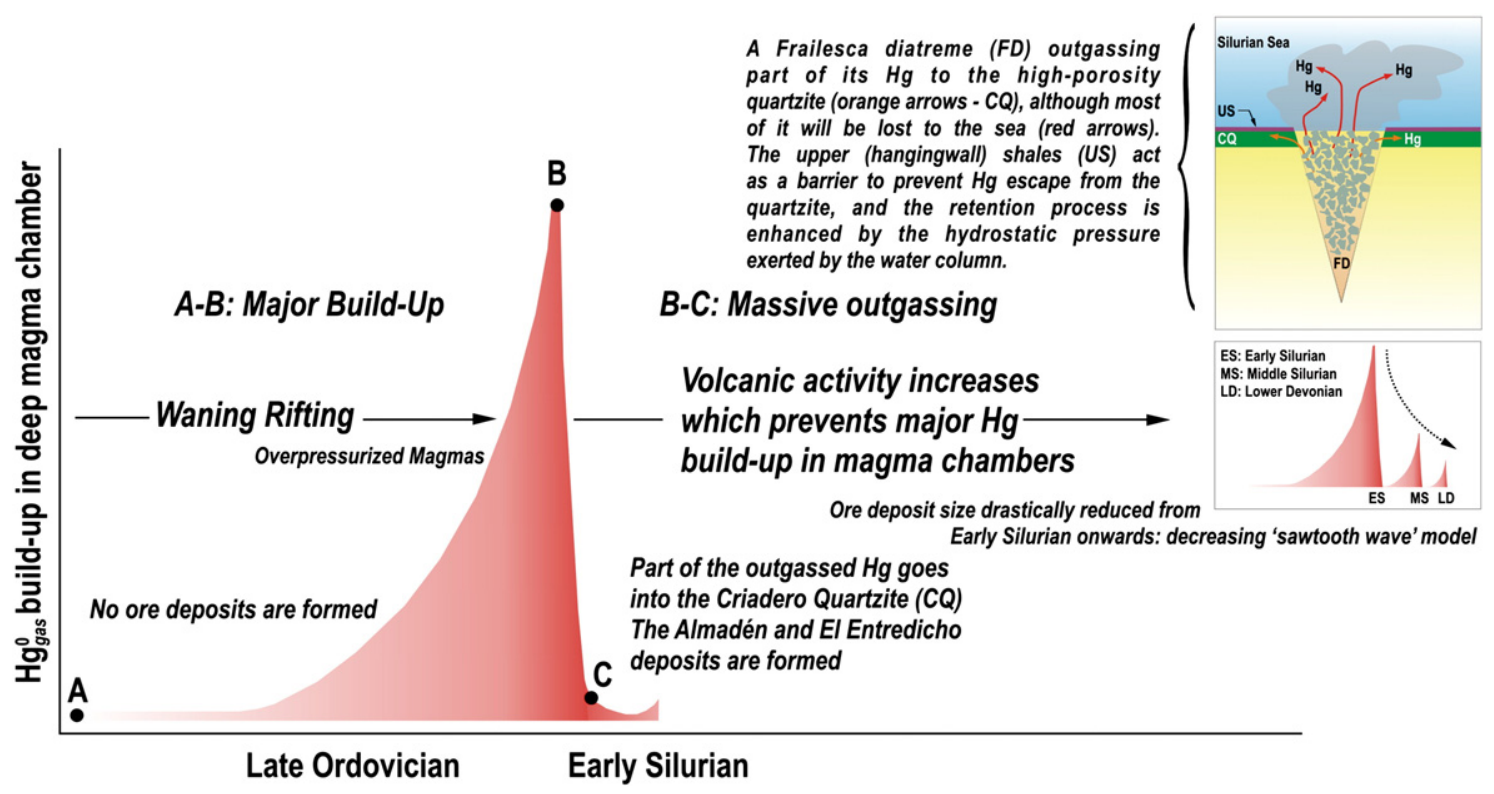

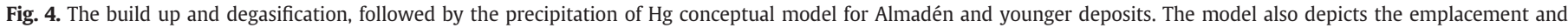
degasification of the Almadén Frailesca diatreme at the sea bottom, and the decrease in magmatic Hg build up from Silurian to Devonian time.

provided by the water column. 2. The Criadero Quartzite (CQ) must have had some degree of consolidation before mercury was introduced (otherwise mercury would have escaped), but it is unlikely that the unit had undergone complete diagenesis, because in that case most of its effective porosity would have been lost. In this respect, we suggest that mercury was introduced into the CQ unit during or soon after deposition of the upper (hanging wall) shales (US) (Fig. 1, 4). Even if part of the mercury was lost to sea from the Frailesca diatreme, the pressure exerted by the water column must have played a role impeding a large release of mercury from the CQ unit (Fig. 4) as it is likely to occur at hot-spring, subaerial geyser type scenarios. The US (impermeable) unit would have further contributed to the sealing of the CQ Hg reservoir (Fig. 4), and serves as an indicator of rising sea level (e.g., Loydel et al., 2009) and therefore increased hydrostatic pressure in this realm during ore deposition time.

\subsection{Final remarks}

As shown by Müller (2002), alkaline rocks have gained much attention among petrologists worldwide, mainly due to their distinct geochemistry, and many geoscientists still consider them as petrological curiosities with an obscure petrogenesis. We could not agree more, their petrogenesis is complex, and the genesis of the mafic volcanic complexes found in intraplate settings is bound to generate bitter discussions. This is quite understandable because the mantle isotopic signatures, degrees of partial melting, participation of the lithosphere (versus) asthenosphere, and mantle metasomatism are not simple matters, therefore they are subjected to multiple interpretations. However, if for Almadén we stick to the basics, a direct relationship to the mantle (whatever the components are involved at the source) is beyond dispute. On the other hand, ore deposition in relation to the alkaline magmatism does not result in a very long list of names, at least regarding $\mathrm{Cu}-\mathrm{Au}$ mineral deposits (Sillitoe, 2002). The Sillitoe's list is even narrower if only volcanic complexes are taken into account. Furthermore, if we only consider the "mantle-derived" "mafic intraplate volcanism", either at oceanic (e.g., Canary Islands, Galapagos, Easter Island, and Hawaii) or continental settings (French Massif Central, Hoggar and Tibesti in northern Africa) not a single significant ore deposit (of any kind) is found. That is what makes Almadén so unique, and why we should keep studying this formidable district. In this regard we would like to see our contribution as 'one step further' (hopefully more than 'a single one') towards a better understanding of this Nature's wonder. Finally, whatever the shortcomings that (most probably) our model may have, we believe that it nonetheless certainly explains: 1) why such a huge amount of mercury was deposited in the Lower Silurian; and 2) why the younger $\mathrm{Hg}$ deposits were progressively smaller as volcanism (and therefore degasification) became more important.

\section{Acknowledgments}

This work was partially supported by grant CGL2009-13171-C03 from the Spanish Ministry of Science and Innovation. Discussions through the years with Angel Hernández, Saturnino Lorenzo, Fernando Palero, and José Munhá (among others) have added greatly to our understanding of the Almadén Mining District. Stephen Kesler and an anonymous reviewer are thanked for the many comments and suggestions that helped to improve the manuscript. The journal editors that handled this paper are thanked for their help.

\section{References}

Arneth, M., Matzigkeit, U., 1986. Laboratory simulated thermal maturation of different types of sediments from the Williston Basin, North America: effects of the production rates, the isotopic and organo-chemical composition of various pyrolysis products. Chem. Geol. 58, 339-360.

Azor, A., González-Lodeiro, F., Simancas, J.F., 1994. Tectonic evolution of the boundary between the Central Iberian and Ossa-Morena zones (Variscan belt, southwest Spain). Tectonics 13, 45-61.

Bickle, M.J., Alt, J.C., Teagle, D.A.H., 1994. Sulphur transport and sulphur isotope fractionations in ocean floor hydrothermal systems. Mineral. Mag. 58A, 88-89.

Borisenko, A.S., Obolenskiy, A.A., Naumov, E.A., 2005. Global tectonic settings and deep mantle control on $\mathrm{Hg}$ and $\mathrm{Au}-\mathrm{Hg}$ deposits. In: Mao, J., Bierlein, F.P. (Eds.), Mineral Deposit Research: Meeting the Global Challenge. Springer, Berlin, pp. 3-6.

Bowers, T.S., Taylor, H.P., 1985. An integrated chemical and stable isotope model of the origin of midocean ridge hot spring systems. J. Geophys. Res. 90, 583-606.

Brendan Murphy, J., Gutiérrez-Alonso, G., Fernández-Suárez, J., Braid, J.A., 2008 Probing crustal and mantle lithosphere origin through Ordovician volcanic rocks along the Iberian passive margin of Gondwana. Tectonophysics 461, 166-180.

Class, C., Goldstein, S.L., 2005. Evolution of helium isotopes in the Earth's mantle Nature 436, 1107-1112.

Coderre, J.A., Steinhorsson, S., 1977. Natural concentrations of mercury in Iceland. Geochim. Cosmochim. Acta 41, 419-424.

Cox, K.G., Hawkesworth, C.J., 1984. Relative contribution of the crust and mantle to the flood basaltic magmatism, Mahabaleshwar area, Deccan traps. Philos. T. Roy. Soc. A 310, 627-642. 
Dallmeyer, R.D., Martínez García, E., 1990. Pre-Mesozoic Geology of Iberia. Springer-Verlag, Heidelberg, Heidelberg . (427 pp.).

Deines, P., 2002. The carbon isotope geochemistry of mantle xenoliths. Earth Sci. Rev. $58,247-278$.

Doblas, M., López-Ruiz, J., Oyarzun, R., Mahecha, V., Sánchez-Moya, Y., Hoyos, M., Cebriá, J.M., Capote, R., Hernández-Enrile, J.L., Lillo, J., Lunar, R., Ramos, A. Sopeña, A., 1994. Extensional tectonics in the central Iberian Peninsula during the Variscan to Alpine transition. Tectonophysics 238, 95-116.

Dromgoole, E.L., Pasteris, J.D., 1987. Interpretation of the sulfide assemblages in a suite of xenoliths from Kilbourne Hole, New Mexico. Geol. Soc. Am. Spec. Pap. 215 25-46.

Dubé, B., Gosselin, P., 2007. Greenstone-hosted quartz-carbonate vein deposits. In: Goodfellow, W.D., (Ed.), Mineral Deposits of Canada: A Synthesis of Major Deposit-Types, District Metallogeny, the Evolution of Geological Provinces, and Exploration Methods: Geological Association of Canada, Mineral Deposits Division, Special Publication No. 5, p. 49-73.

Eichmann, R., Saupé, F., Schidlowski, M., 1977. Carbon and oxygen isotope studies in rocks of the vicinity of the Almadén mercury deposit (Province of Ciudad Real, Spain). In: Klemm, D.D., Schneider, H.D. (Eds.), Time- and Strata-bound Ore Deposits. Springer Verlag, Berlin, pp. 396-405.

Ellis, A.J., 1979. Explored geothermal systems, In: Barnes, H.L. (Ed.), Geochemistry of Hydrothermal Ore Deposits, 2nd ed. Holt, Rhinehart and Winston, New York, New York, pp. 632-683.

Fitton, J.G., James, D., Kempton, P.D., Ormerod, D.S., Leeman, W.P., 1988. The role of lithospheric mantle in the generation of late Cenozoic basic magmas in the western United States. J. Petrol. Spec. 1, 331-349.

Gasperini, D., Bosch, D., Braga, R., Bondi, M., Macera, P., Morten, L., 2006. Ultramafic xenoliths from the Veneto Volcanic Province (Italy): petrological and geochemical evidence for multiple metasomatism of the SE Alps mantle lithosphere. Geochem. J. 40, 377-404.

Halbach, P., Hansmann, W., Köppel, V., Pracejus, B., 1997. Whole-rock and sulfide leadisotope data from the hydrothermal JADE field in the Okinawa back-arc trough. Mineral. Deposita 32, 70-78.

Hall, C.M., Higueras, P., Kesler, S., Lunar, R., Dong, H., Halliday, A.N., 1997. Dating of alteration episodes related to mercury mineralization in the Almadén district Spain. Earth Planet. Sci. Lett. 148, 287-298.

Hart, W.K., Woldegabriel, G., Walter, R.C., Mertzman, S.A., 1989. Basaltic volcanism in Ethiopia: constraints on continental rifting and mantle interactions. J. Geophys. Res. 94, 7731-7748.

Helo, C., Longpré, M.A., Shimuzi, N., Clague, D.A., Stix, J., 2011. Explosive eruptions at mid-ocean ridges driven by $\mathrm{CO}_{2}$-rich magmas. Nat. Geosci. 4, 260-263.

Hemley, J.J., Montoya, J.W., Nigrini, A., Vincent, H.A., 1971. Some alteration reactions in the system $\mathrm{CaO}-\mathrm{Al}_{2} \mathrm{O}_{3}-\mathrm{SiO}_{2}-\mathrm{H}_{2} \mathrm{O}$. Mineral. Geol. Soc. Japan Spec. (2), 58-63.

Hernández, A., Jébrak, M., Higueras, P., Oyarzun, R., Morata, D., Munhá, J., 1999. The Almadén mercury mining district. Mineral. Deposita 34, 539-548.

Higueras, P., 1995. Procesos petrogenéticos y de alteración de las rocas magmáticas asociadas a las mineralizaciones de mercurio del distrito de Almadén. Ediciones de la Universidad de Castilla-La Mancha, Cuenca (Spain), (270 pp.).

Higueras, P., Munhá, J., 1993. Geochemical constraints on the petrogenesis of mafic magmas in the Almadén mercury mining district. Terra Abstracts 6, 12-13.

Higueras, P., Morata, D., Munhá, J., 1995. Metamorfismo de bajo grado en facies prehnita-pumpellyita en las metabasitas del Sinclinal de Almadén. Bol. Soc. Esp. Miner. 18, 111-125.

Higueras, P., Oyarzun, R., Lunar, R., Sierra, J., Parras, J., 1999a. The Las Cuevas deposit Almadén district (Spain): an unusual case of deep-seated advanced argillic alteration related to mercury mineralization. Mineral. Deposita 34, 211-214.

Higueras, P., Saupé, F., Tena, J.C., 1999b. Episodios de mineralización únicos en los yacimientos de mercurio de Almadén: evidencias isotópicas en el yacimiento de Las Cuevas. Geogaceta 25, 107-109.

Higueras, P., Munhá, J., Oyarzun, R., Tassinari, C.C.G., Ruiz, I.R., 2005. First lead isotopic data for cinnabar in the Almadén district (Spain): implications for the genesis of the mercury deposits. Mineral. Deposita 40, 115-122.

Higueras, P., Llanos, W., García, M.E., Millán, R., Serrano, C., 2012. Mercury vapor emissions from the Ingenios in Potosí (Bolivia). J. Explor. Geochem. 116-117, 1-7.

Hoffman, A.W., Jochum, K.P., Seufert, M., White, W.M., 1986. Nb and Pb in oceanic basalts: new constraints on mantle evolution. Earth Planet. Sci. Lett. 79, 33-45.

Jannasch, H.W., 1989. Sulphur Emission and Transformations at Deep Sea Hydrothermal Vents. In: Brimblecombe, P., Lein, A.Yu (Eds.), Evolution of the Global Biogeochemical Sulphur Cycle. John Wiley \& Sons, Chichester, pp. 181-190.

Jébrak, M., Higueras, P., Hernández, A., Marcoux, E., 1997. Datos geoquímicos e isotópicos sobre el yacimiento de Nuevo Entredicho, Almadén, España. Bol. Soc. Esp. Mineral. 20A, 87-88.

Kampschulte, A., Strauss, H., 2004. The sulfur isotopic evolution of Phanerozoic seawater based on the analysis of structurally substituted sulfate in carbonates. Chem. Geol. 204, 255-286.

Kishida, A., Kerrich, R., 1987. Hydrothermal alteration zoning and gold concentration at the Kerr-Addison Archean lode gold deposit, Kirkland Lake, Ontario. Econ. Geol. 82 649-690.

Knauth, P.L., Lowe, D.R., 1978. Oxygen isotope geochemistry of cherts from the Onverwacht Group (3.4 billion years), Transvaal, South Africa, with implications for secular variations in the isotopic composition of cherts. Earth Planet. Sci. Lett. 41, 209-222.

Krabbenhoft, D., Schuster, P., 2002. Glacial ice cores reveal a record of natural and anthropogenic atmospheric mercury deposition for the last 270 years. USGS Fact Sheet FS-051-02, U.S. Department of the Interior, and U.S. Geological Survey, (2 pp.).

Krupp, R.E., Seward, T.M., 1987. The Rotokawa geothermal system, New Zealand: an active epithermal gold-depositing environment. Econ. Geol. 82, 1109-1129.
Lauretta, D.S., Klaue, B., Blum, J.D., Buseck, P.R., 2001. Mercury abundances and isotopic compositions in the Murchison (CM) and Allende (CV) carbonaceous chondrites. Geochim. Cosmochim. Acta 65, 2807-2818.

López-Ruiz, J., Cebriá, J.M., Doblas, M., Oyarzun, R., Hoyos, M., Martín, C., 1993. The late Cenozoic alkaline volcanism of the Central Iberian Peninsula (Calatrava Volcanic Province, Spain): intraplate volcanism related to extensional tectonics. J. Geol. Soc. London 150, 915-922.

Loydel, D.K., Sarmiento, G.N., Storch, P., Gutiérrez Marcos, J.C., 2009. Graptolite and conodont biostratigraphy of the upper Telychian-lower Sheinwoodian (Llandovery-Wenlock) strata, Jabalón River section, Corral de Calatrava, central Spain. Geol. Mag. 146, 187-198.

Machel, H.G., 2001. Bacterial and thermochemical sulfate reduction in diagenetic settings - old and new insights. Sediment. Geol. 140, 143-175.

Mathews, A., Katz, A., 1977. Oxygen isotope fractionation during dolomitization of calcium carbonate. Geochim. Cosmochim. Acta 41, 1431-1438.

Meschede, M., 1986. A method for discriminating between different type of mid-ocean ridge basalts and continental tholeiites with the Nb-Zr-Y diagram. Chem. Geol. 56, 207-218.

Morata, D., Higueras, P., Domínguez-Bella, S., Parras, J., Velasco, F., Aparicio, P., 2001. Fuchsite and other Cr-rich phyllosilicates in ultrabasic enclaves from the Almadén mercury mining district, Spain. Clay Minerals 36, 345-354.

Morteani, G., Ruggieri, G., Möller, P., Preinfalk, C., 2011. Geothermal mineralized scales in the pipe system of the geothermal Piancastagnaio power plant (Mt. Amiata geothermal area): a key to understand the stibnite, cinnabarite and gold mineralization of Tuscany (central Italy). Mineral. Deposita 46, 197-210.

Müller, D., 2002. Gold-copper mineralization in alkaline rocks. Mineral. Deposita 37, $1-3$.

Mumin, A.H., Fleet, M.E., Longstaffe, F.J., 1996. Evolution of hydrothermal fluids in the Ashanti gold belt, Ghana: stable isotope geochemistry of carbonates, graphite and quartz. Econ. Geol. 91, 135-148.

Munhá, J., Barriga, F.J.A.S., Kerrich, R., 1986. High ${ }^{18} \mathrm{O}$ ore forming fluids in volcanichosted base metal massive sulphide deposits: Geologic, ${ }^{18} \mathrm{O} /{ }^{16} \mathrm{O}$, and $\mathrm{D} / \mathrm{H}$ evidence from the Iberian Pyrite Belt; Crandon, Wisconsin; and Blue Hill, Maine. Econ. Geol. $81,530-552$.

Nägler, T.F., Schäfer, H.J., Gebauer, D., 1992. A Sm-Nd isochron on pelites 1 Ga in excess of their depositional age and its possible significance. Geochim. Cosmochim. Acta 56, 789-795.

Nriagu, J., Becker, Ch., 2003. Volcanic emissions of mercury to the atmosphere: global and regional inventories. Sci. Total Environ. 304, 3-12.

O'Neil,, J.R., 1987. Preservation of H, C, and O isotopic ratios in the low temperature environment. In: Kyser, T.K. (Ed.), Short Course in Stable Isotope Geochemistry of Low Temperature Fluids, 13. Mineralogical Association of Canada, Québec, pp. 85-128.

Ohmoto, H., 1972. Systematics of sulfur and carbon isotopes in hydrothermal ore deposits. Econ. Geol. 67, 551-579.

Ohmoto, H., Goldhaber, M.B., 1997. Sulfur and carbon isotopes. In: Barnes, H.L. (Ed.), Geochemistry of Hydrothermal Ore Deposits. Wiley, New York, pp. 517-611.

Oppenheimer, C., 2004. Volcanic degassing. In: Rudnick, R.L. (Ed.), Treatise on Geochemistry, vol. 3. Elsevier, Amsterdam, pp. 123-166 (The crust).

Oyarzun, R., Ortega, L., Sierra, J., Lunar, R., Oyarzún, J., 1996. The manto-type gold deposits of Andacollo (Chile) revisited: a model based on fluid inclusion and geological evidence. Econ. Geol. 91, 1298-1309.

Oyarzun, R., Márquez, A., Lillo, J., López, I., Rivera, S., 2001. Giant versus small porphyry copper deposits of Cenozoic age in northern Chile: adakitic versus normal calcalkaline magmatism. Mineral. Deposita 36, 794-798.

Oyarzun, R., Oyarzún, J., Ménard, J.J., Lillo, J., 2003. The Cretaceous iron belt of northern Chile: role of oceanic plates, a superplume event, and a major shear zone. Mineral. Deposita 38, 640-646.

Oyarzun, R., Lillo, J., Sánchez-Hernández, J.C., Higueras, P., 2005. Pre-industrial metal anomalies in ice cores: a simplified reassessment of windborne soil dust contribution and volcanic activity during the last glaciations. Int. Geol. Rev. 47, 1120-1130.

Palero, F., Lorenzo, S., 2009. Mercury mineralization in the region of Almadén. In: García-Cortés, A., Agueda-Villar, J., Palacio Suárez-Valgrande, J., Salvador González, C.I. (Eds.), Spanish Geological Frameworks and Geosites: An Approach to Spanish Geological Heritage of International Relevance. Instituto Geológico y Minero de España, Madrid, pp. 65-72.

Pasteris, J.D., 1996. Mount Pinatubo volcano and "negative" porphyry copper deposits. Geology 24, 1075-1078.

Pearce, J.A., 1982. Trace elements characteristics of lavas from destructive plate boundaries. In: Thorpe, R.S. (Ed.), Andesites: Orogenic Andesites and Related Rocks. Wiley, Chichester, pp. 525-548

Pyle, D.M., Mather, T.A., 2003. The importance of volcanic emissions for the global atmospheric mercury cycle. Atmos. Environ. 37, 5115-5124.

Renne, P.R., Zichao, Z., Richards, M.A., Black, M.T., Basu, A.R., 1995. Synchrony and causal relations between Permian-Triassic boundary crises and Siberian flood volcanism. Science 269, 1413-1416.

Robinson, B.W., 1974. Carbon and oxygen isotopic equilibria in hydrothermal calcites. Geochem. J. 9, 43-46.

Rytuba, J.J., 2004a. Descriptive model of hot-spring Hg. In: Cox, D.P., Singer, D.A. (Eds.), Mineral Deposit Models (USGS, http://pubs.usgs.gov/bul/b1693/html/bullfrms. htm, accessed: May 2012).

Rytuba, J.J., 2004b. Grade and tonnage model of hot-spring Hg. In: Cox, D.P., Singer, D.A. (Eds.), Mineral deposit models (USGS, http://pubs.usgs.gov/bul/b1693/html/ bullfrms.htm, accessed: May 2012).

Rytuba, J.J., Rye, R.O., Hernández, A.M., Dean, J.A., Arribas, A., 1989. Genesis of Almadén type mercury deposits, Almadén, Spain. International Geologic Congress, 28th, Washington D.C., USA, 9-19 July 1989, Abstracts with Program, 2, 741. 
Saltzman, M.R., 2002. Carbon isotope $\left(\delta^{13} \mathrm{C}\right)$ stratigraphy across the Silurian-Devonian transition in North America: evidence for a perturbation of the global carbon cycle. Palaeogeogr. Palaeoclimatol. 187, 83-100.

Sanei, H., Grasby, S.E., Beauchamp, B., 2012. Latest Permian mercury anomalies. Geology 40, 63-66.

Saupé, F., 1990. The geology of the Almadén mercury deposit. Econ. Geol. 85, $482-510$.

Saupé, F., Arnold, M., 1992. Sulphur isotope geochemistry of the ores and country rocks at the Almadén mercury deposit, Ciudad Real, Spain. Geochim. Cosmochim. Acta 56, 3765-3780.

Seal, R.R., 2006. Sulfur isotope geochemistry of sulfide minerals. Rev. Mineral. Geochem. 61, 633-677.

Shepard, S.M.F., 1986. Characterization and isotopic variations in natural waters. In: Valley, J.V., Taylor, H.P., O'Neil, J.R. (Eds.), Stable Isotopes in High Temperature Geological Processes. Rev. Mineral. 16, 165-184.

Sibson, R.H., 1990. Faulting and fluid flow. In: Nesbitt, B.E. (Ed.), Short course on Fluids in Tectonically Active Regimes of the Continental Crust, 18. Mineralogical Association of Canada, Québec, pp. 93-132.

Sillitoe, R.H., 2002. Some metallogenic features of gold and copper deposits related to alkaline rocks and consequences for exploration. Mineral. Deposita 37, 4-13.

Simancas, F., Expósito, I., Azor, A., Martínez-Poyatos, D., González-Lodeiro, F., 2004 From the Cadomian orogenesis to the Early Palaeozoic Variscan rifting in Southwest Iberia. J. Iber. Geol. 30, 53-71.

Smith, C.N., Kesler, S.E., Blum, J.D., Rytuba, J.J., 2008. Isotope geochemistry of mercury in source rocks, mineral deposits and spring deposits of the California Coast Ranges, USA. Earth Planet. Sci. Lett. 269, 399-407.

Stakes, D., O'Neil, J.R., 1982. Mineralogy and stable isotope geochemistry of hydrothermally altered oceanic rocks. Earth Planet. Sci. Lett. 57, 285-304.
Taylor, S.R., McLennan, S.M., 1985. The Continental Crust: Its Composition and Evolution. Blackwell, Oxford, p. 328.

Varekamp, J.C., Buseck, P.R., 1981. Mercury emissions from Mount St Helens during September 1980. Nature 293, 555-556.

Varekamp, J.C., Buseck, P.R., 1984a. The speciation of mercury in hydrothermal systems, with applications to ore deposition. Geochim. Cosmochim. Acta 48, $177-185$.

Varekamp, J.C., Buseck, P.R., 1984b. Changing mercury anomalies in Long Valley, California: indications for magma movement or seismic activity. Geology 12 283-286.

Viladevall, M., Font, X., Navarro, A., 1999. Geochemical mercury survey in the Azogue Valley (Betic area, SE Spain). J. Geochem. Explor. 66, 27-35.

Villaseca, C., Orejana, D., Belousova, E., Jeffries, T.E., 2011. U-Pb isotopic ages and Hf isotope composition of zircons in Variscan gabbros from central Spain: evidence of variable crustal contamination. Mineral. Petrol. 101, 151-167.

White, R.S., McKenzie, D., 1995. Mantle plumes and flood basalts. J. Geophys. Res. 100, $17543-17585$.

Wilson, M., 1989. Igneous petrogenesis. A Global Tectonic Approach. Unwyn Hyman, London, p. 466

Wilson, M., 1993. Geochemical signatures of oceanic and continental basalts: a key to mantle dynamics? J. Geol. Soc. London 150, 977-990.

Winchester, J.A., Floyd, P.A., 1977. Geochemical discrimination of different magma series and their differentiation products using immobile elements. Chem. Geol 20, 325-343.

Yardley, B., 1989. An Introduction to Metamorphic Petrology. Longman, Singapore, p. 264. 